\title{
Influence of heat treatment on FVIII:C recovery from freeze dried cryoprecipitate
}

\author{
A G BENNY,* P A OCKELFORD $\ddagger$ A S JOHNS, $\dagger$ R H SCOTT,* D G WOODFIELD, $\ddagger$ \\ E W BERRY† \\ From the *Blood Products Laboratory, Auckland Regional Blood Centre, $\uparrow$ Department of Haematology, \\ Auckland Hospital, and $\$$ School of Medicine, University of Auckland, New Zealand
}

SUMMARY A standard lyophilised triple cryoprecipitate preparation, stabilised by the addition of Synthamin 17 , was heat treated at $60^{\circ} \mathrm{C}$ for 48 hours. The total protein content, factor VIII concentration, and factor VIII recovery were not affected by the heat treatment procedure. Heat treatment did not influence the reconstitution characteristics of the freeze dried preparation and there were no side effects during or after administration. The mean in vivo rise of factor VIII from infused heat treated triple cryoprecipitate was 2.5 (SD 0.9) \%/unit/kg with a half life of $13 \cdot 1$ (3.1) hours. These results compare favourably with those obtained using non-heated triple cryoprecipitate. Cryoprecipitate can be heat treated without adversely influencing factor VIII recovery, and the ability to prepare a heat treated cryoprecipitate means that a small pool high yield factor VIII preparation can again be used in routine clinical practice.

The heat treatment of large pool factor VIII concentrates is universally recommended for the inactivation of the human immunodeficiency virus (HIV). ${ }^{\prime}$ Although effective against HIV, most heat treatment procedures fail to inactivate completely hepatitis viruses which can be present in blood products prepared from large plasma pools. ${ }^{2}$

Cryoprecipitate has been widely used for the management of patients with an occasional requirement for factor VIII replacement or in young, newly diagnosed haemophiliacs. ${ }^{3}$ This product can be prepared by any modestly equipped blood products laboratory. The material also has the considerable production advantages of a relatively higher yield of factor VIII and a small production pool with a correspondingly reduced risk of contamination with hepatitis virus. ${ }^{45}$ Confirmed HIV infection treated with non-heated cryoprecipitate means, however, that this product is no longer acceptable for the routine treatment of patients with haemophilia. ${ }^{6}$

The high concentrations of fibrinogen and other labile plasma proteins have previously caused practical difficulties in preparing heat treated cryoprecipitate preparations. In vitro studies using amino acid mixtures to stabilise the proteins in cryoprecipitate during heat treatment have now been reported. ${ }^{7}$ The addition of the amino acid mixture Synthamin 17 has enhanced stability of

Accepted for publication 7 April 1988 cryoprecipitate during heat treatment. We now report favourable in vitro recovery of factor VIII following the infusion of heat treated cryoprecipitate into patients with classic haemophilia.

\section{Material and methods}

Blood $(430 \mathrm{ml})$ was collected from random, healthy donors into $63 \mathrm{ml}$ citrate-phosphate-dextrose (CPD) anticoagulant in the primary bag of a triple blood pack (Tuta Laboratories, Australia). The cryoprecipitate was recovered as previously described ${ }^{8}$ and, after the addition of $15 \mathrm{ml}$ of Synthamin 17-glycine buffer (Synthamin 0.38\% w/v, 0.08 M glycine, 0.011 M sodium citrate, $\mathrm{pH} 6 \cdot 1$ ), aseptically injected into each bag using a disposable dispenser (Pharm-Aide, American Pharmaseal Laboratories, USA). Three bags were connected to a $120 \mathrm{ml}$ MRC plasma bottle using a transfer set (Codan BC 333, Portugal) and the cryoprecipitate in the bags resolubilised by briefly immersing the lower $60 \mathrm{~mm}$ of each bag in a $30^{\circ} \mathrm{C}$ water bath. The cryoprecipitates were pooled by gravity transfer and immediately frozen at $-30^{\circ} \mathrm{C}$.

The product was freeze dried in a Virtis 250 SRC freeze drier at an initial shelf temperature of $30^{\circ} \mathrm{C}$ and a maximum product temperature of $15^{\circ} \mathrm{C}$. The bottles were closed under vacuum in the freeze drier.

The freeze dried product was heat treated in a hot air oven at $60^{\circ} \mathrm{C}$ for 48 hours before reconstituting with 40 $\mathrm{ml}$ of sterile water for intravenous administration. 
Factor VIII assays of both the concentrate and patient plasmas were performed using a standard one stage manual assay and an artificial substrate.' The plasma standard was calibrated against the second WHO international reference plasma. The coefficient of variation was $\pm 13 \%$. Von Willebrand factor (VWF) multimeric analysis on the heated and unheated cryoprecipitate preparations was performed as previously described. ${ }^{10}$ Fibrinogen was assayed using a spectrophotometric modification of a standard method." Total protein was estimated using a modified Biuret method. ${ }^{12}$

Fourteen patients with severe or moderately severe classic haemophilia, who were not actively bleeding, participated in the two recovery trials using the nonheated and heat treated cryoprecipitate. No patient has received blood products during the preceding four days. The product was administered as a single intravenous infusion over 20 minutes through a butterfly needle inserted into a peripheral vein. The age range of the recipients was 7-45 years and body weight varied between $25-80 \mathrm{~kg}$.

In vitro factor VIII concentrations were measured by separate venipuncture before and immediately after infusion (30-45 minutes). In the six patients in whom the half life ( $\left.\mathrm{T} \frac{1}{2}\right)$ was determined, additional samples were taken at six and $\mathbf{2 4}$ hours after administration. Factor VIII recovery (the $K$ value) was calculated from the product of the observed increment in plasma factor VIII and the plasma volume, relative to the expected increase based on the number of factor VIII units administered. For the recovery studies the plasma volume determination was based on body weight calculation using $42 \mathrm{ml} / \mathrm{kg}$ with an haematocrit correction. ${ }^{13}$ The half life $\left(\mathrm{T} \frac{1}{2}\right)$ was calculated from the factor VIII survival curve as described previously. ${ }^{14}$ The trial was approved by the medical ethical committee, Auckland Hospital, Auckland, New Zealand.

\section{Results}

Forty eight bottles of unheated cryoprecipitate and 16 bottles of cryoprecipitate, sampled after heat treatment, were randomly selected for comparative analysis of protein content and reconstitution characteristics (table 1). The reconstitution time, factor VIII potency, yield from starting plasma and VWF multimeric composition (data not shown) were not significantly different after heat exposure. The reconstituted solution was available for infusion within 10 minutes of addition of the sterile water and did not contain visible particulate matter. A filter (Alpha Micron-40, Alpha Therapeutic Corporation, California, USA) was used to draw the material into the syringe.

There were no adverse local or systemic reactions
Table 1 Comparison of cryoprecipitate before and after heat treatment (minutes)

\begin{tabular}{lll}
\hline & $\begin{array}{l}\text { Before heat } \\
\text { treatment }\end{array}$ & $\begin{array}{l}\text { After heat } \\
\text { treatment }\end{array}$ \\
\hline Factor VIII C (U/ml) & $7 \cdot 3$ & $6 \cdot 0$ \\
Fibrinogen (mg/ml) & $18 \cdot 8$ & $9 \cdot 0$ \\
Total protein (mg/ml) & $25 \cdot 1$ & $32 \cdot 0$ \\
Factor VIII specific activity (U/mg) & $0 \cdot 3$ & $0 \cdot 2$ \\
Reconstitution time (SD) & $8(1 \cdot 5)$ & $7(1 \cdot 2)$ \\
pH after recovery & $7 \cdot 2$ & $7 \cdot 3$ \\
Citrate concentration (mM/L) & 15 & 11 \\
Factor VIII recovery (U/kg plasma) & 414 & 367 \\
\hline
\end{tabular}

Table 2 Mean (SD) dosage, recovery, and half life determinations for unheated and heat treated cryoprecipitates

\begin{tabular}{|c|c|c|c|c|}
\hline Patients & $\begin{array}{l}\text { Dose } \\
\text { (units/kg) }\end{array}$ & $\begin{array}{l}\text { Per cent } \\
\text { rise/u/kg }\end{array}$ & $\begin{array}{l}\text { Recovery } \\
(K)\end{array}$ & $\begin{array}{l}\text { Half life } \\
\text { (hours) }\end{array}$ \\
\hline $\begin{array}{l}\text { Before heat }(n=6) \\
\text { After heat }(n=14)\end{array}$ & $\begin{array}{l}12 \cdot 6 \\
15 \cdot 8\end{array}$ & $\begin{array}{l}1.94(0.7) \\
2.5(0.9)\end{array}$ & $\begin{array}{l}1 \cdot 6(0.2) \\
1 \cdot 1(0.5)\end{array}$ & $\begin{array}{l}12 \cdot 0(1 \cdot 75) \\
13 \cdot 1(3 \cdot 1)^{*}\end{array}$ \\
\hline
\end{tabular}

*The half life calculation was determined on the data derived from six patients.

during or after the intravenous infusion. The in vitro recovery, expressed as the mean percentage rise/unit/ $\mathrm{kg}$ of factor VIII infused, the mean recoveries, and mean half life determinations after administration of the two cryoprecipitate preparations is shown in table 2. The six recipients of the untreated material participated in both trials.

\section{Discussion}

In a recent study, using a controlled pore glass high purity factor VIII concentrate, we confirmed the ability of the amino acid mixture Synthamin 17 to stabilise factor VIII following heat treatment at $60^{\circ} \mathrm{C}$ for 72 hours. $^{15}$ After the addition of Synthamin 17, heat treatment of the freeze dried concentrate resulted in less than $10 \%$ further loss of factor VIII activity, with a final $25 \%$ yield of factor VIII from the starting plasma. Infusion of this stabilised, and heat treated concentrate into haemophiliac patients resulted in excellent in vitro factor VIII recovery.

The amino acid mixture Synthamin 17 also seems to confer stability to heat treatment on a relatively crude cryoprecipitate preparation. ${ }^{6}$ This study now provides further evidence that the heat treatment procedure under these conditions does not adversely influence the solubility or reconstitution of the cryoprecipitate. There were no unexpected side effects during infusion and the in vitro recovery of the infused factor VIII was not significantly different from that observed with unheated cryoprecipitate.

The protective effects of a lowered $\mathrm{pH}$ on the stability of cryoprecipitate have recently been shown ${ }^{16}$ and have been suggested as an alternative to the 
addition of stabilisers such as Synthamin 17 in the preparation of heat inactivated cryoprecipitate. The report concluded that there were considerable disadvantages with Synthamin 17, which included increased residual moisture resulting in discolouration of the lyophilised material, the potential for a stabilising effect of the amino acids on the virus, and an increase in production costs. In our experience careful monitoring of the freeze drying procedure minimises potential discolouration due to a high residual moisture content. In addition, some residual moisture in the freeze dried preparation may be necessary for effective inactivation of HIV virus (Foster P, personal communication). The added benefit of using Synthamin 17 stabilisation is its relative simplicity as a minor modification of an existing successful cryoprecipitate preparation technique and this greatly outweighs any possible disadvantages attributable to an increase in cost. The considerable buffering capacity of Synthamin 17 also reduces interbatch variability due to significant fluctuations of the $\mathrm{pH}$ following lyophilisation.

The method used in this report is now in routine use in our laboratory for preparing a heat treated cryoprecipitate from a triple donor pool for the management of classic haemophilia. The material has also been used to treat patients with von Willebrand's disease undergoing surgical procedures. We are presently producing 1.6 million factor VIII units every year as heat treated cryoprecipitate.

The financial support of the Blood Foundation of New Zealand and the Auckland Medical Research Foundation, and the technical advice from Dr Jan Over (CLB, Amsterdam) are gratefully acknowledged. We thank Stephanie Forde, Haemophilia Centre Nurse, and Miss Kim Brown for skilled secretarial assistance.

\section{References}

1 National Haemophilia Foundation Medical and Scientific Advisory Council. 1984. Recommendations concerning AIDS and therapy of haemophilia. New York: National Haemophilia Foundation, 984:1-2.

2 Colombo M, Mannucci PM, et al. and the European Study Group. Transmission of non-A, non-B hepatitis by heat treated factor VIII concentrate. Lancet 1985;ii:1-4.

3 Menitove JE, Spero JA, Richards WA, et al. Prepooled cryoprecipitate for treatment of haemophilia A. Transfusion 1983;23:265-7.

4 Smith KJ, Hodges PA. Preparation of pooled cryoprecipitate for treatment of haemophilia $\mathrm{A}$ in a home care program. Transfusion 1984;24:520-3.

5 Hambley H, Davidson JF, Walker IS, Small M, Prentice CRM. Freeze dried cryoprecipitate: a clinical evaluation. J Clin Pathol 1983;36:574-6.

6 Ragni MV, Tegtmeier GE, Levy JA, et al. AIDS retrovirus antibodies in haemophiliacs treated with factor VIII or factor IX concentrates, cryoprecipitate or fresh frozen plasma: prevalence, seroconversion rate and clinical correlations. Blood 1986;67:592-5.

7 Margolis J, Eisen M. Stabilising effect of amino acids on factor VIII in lyophilised cryoprecipitate. Lancet 1984;ii:1345.

8 Benny AG, Scott RH. Improved recovery of factor VIII from plasma. NZ J Med Lab Tech 1983;37:79-82.

9 Chantarangkul V, Ingram GIC, Thorn MB, Darby SC. An artificial haemophiliac plasma for one-stage factor VIII assay. Br J Haematol 1978;40:471-88.

10 Ruggeri ZM, Mannucci PH, Lombardi R, Federici AB, Zimmerman TS. Multimeric composition of factor VIII/von Willebrand factor following administration of DDAVP. Implications of pathophysiology and therapy of von Willebrand's disease subtypes. Blood 1982;59:1272-8.

11 Von Clauss A. Gerunnungsphysiologische schnellmethode zur bestinimung des fibrinogens. Acta Haematol 1957;17:237-46.

12 Gornal AG, Barda Will CJ, David MM. Determination of serum proteins by means of the Biuret reaction. J Biol Chem 1949;177:751-66.

13 International Committee for Standardization in Haematology. Standard techniques for the measurement of red cell and plasma volume. Br J Haematol 1973;25:801-15.

14 Abilgaard CF, Cornet JA, Fort E, Schulman I. The in vivo longevity of antihaemophilic factor (factor VIII). Br J Haematol 1964;10:225-37.

15 Ockelford PA, Benny AG, Berry EW, Johns AS, Woodfield DG. Controlled pore glass factor VIII concentrate: influence of heat treatment. Pathology 1987;19:56-7.

16 Skjonsberg $\mathrm{OH}$, Gravern K, Kierulf P, Vaeret A, Godal HC. The influence of $\mathrm{pH}$ on heat denaturation of antihaemophilic cryoprecipitate. Thromb Res 1987;47:183-90.

Requests for reprints to: Dr PA Ockelford, Department of Immunobiology, School of Medicine, Private Bag, Auckland, New Zealand. 